\title{
Adsorption of Calcium(II), Cadmium(II) and Copper(II) Ions from Water by Prepared Silicon-Aluminum-Zirconium Oxide Using Sol-Gel Process
}

\author{
Cristiano N. da Silva, ${ }^{a, b}$ Maiyara C. Prete, ${ }^{c}$ César R. T. Tarley, ${ }^{c, d}$ Júlio C. Afonso ${ }^{\circledR *, a}$ and \\ Emerson S. Ribeiro ${ }^{(*, a, b}$ \\ ${ }^{a}$ Instituto de Química, Universidade Federal do Rio de Janeiro (UFRJ), CT, Bloco A, \\ Cidade Universitária, Ilha do Fundão, 21941-909 Rio de Janeiro-RJ, Brazil \\ ${ }^{b}$ Instituto Nacional de Tecnologias Alternativas para Detecção, Avaliação Toxicológica e Remoção \\ de Micropoluentes e Radioativos (INCT-DATREM), Instituto de Química, \\ Universidade Estadual Paulista (Unesp), CP 355, 14800-900 Araraquara-SP, Brazil \\ 'Departamento de Química, Universidade Estadual de Londrina (UEL), \\ 86051-990 Londrina-PR, Brazil \\ ${ }^{d}$ Instituto Nacional de Ciência e Tecnologia (INCT) em Bioanalítica, \\ Departamento de Química Analítica, Instituto de Química, \\ Universidade Estadual de Campinas (UNICAMP), 13083-970 Campinas-SP, Brazil
}

\begin{abstract}
Ternary oxide silica-alumina-zirconia $\left(\mathrm{SiO}_{2} / \mathrm{Al}_{2} \mathrm{O}_{3} / \mathrm{ZrO}_{2}\right)$ obtained by the sol-gel process was applied as novel adsorbent of ions in aqueous solution. Batch isotherms were performed using standard $\mathrm{Cu}^{\mathrm{II}}, \mathrm{Cd}^{\mathrm{II}}$ and $\mathrm{Ca}^{\mathrm{II}}$ solutions at variable $\mathrm{pH}$ and different concentrations. Adsorption capacity was best at weakly acidic $\mathrm{pH}$. The maximum adsorption capacities were $2.28 \mathrm{mg} \mathrm{g}^{-1}$ for $\mathrm{Ca}^{\mathrm{II}}, 9.89 \mathrm{mg} \mathrm{g}^{-1}$ for $\mathrm{Cd}^{\mathrm{II}}$, and $14.88 \mathrm{mg} \mathrm{g}^{-1}$ for $\mathrm{Cu}^{\mathrm{II}}$. The adsorption data fitted well to the single and dual-site Langmuir-Freundlich isotherm models. However, since the adsorption is very low in the sites with high energy, the single-site Langmuir-Freundlich provided a good fit as well. Whereas, the site responsible for the most ion adsorption was assigned to the $\mathrm{Zr}-\mathrm{OH}$ group. A real sample of produced water was also tested. The new adsorbent showed a wide ability to retain many metal ions (alkali-earth, transition, and p-block metals) and even some anions were also caught by the adsorbent. The ternary oxide silica-alumina-zirconia was found to be a promising alternative adsorbent for metal ions in aqueous media.
\end{abstract}

Keywords: ternary oxide, $\mathrm{SiO}_{2} / \mathrm{Al}_{2} \mathrm{O}_{3} / \mathrm{ZrO}_{2}$, metal ions adsorption, isotherm, sol-gel process

\section{Introduction}

The presence of potentially toxic metal ions in wastewater, sediments, and soils has an anthropic origin as their main source and is nowadays an important environmental issue due to their toxicity to living beings. ${ }^{1}$ Among the various treatment technologies, adsorption is a fast and wide-ranging method for removing metal ions with high efficiency and low cost. Various materials, such as zeolites, ${ }^{2,3}$ nanomaterials ${ }^{4-9}$ and polymeric materials, ${ }^{10,11}$ have been used as adsorbents for the removal of toxic and nontoxic metal ions from wastewater. ${ }^{12,13}$

Calcium is the most abundant metal in the human body, corresponding to 1 to $2 \mathrm{wt}$.\% of its mass. This element is

*e-mail: julio@iq.ufrj.br; emersonsr@iq.ufrj.br essential to the formation and maintenance of the bone matrix and stabilization of the membranes of excitable cells such as muscles and nerves. It also takes part in the blood clotting process, the activity of several enzymes and the growth and development of bones and teeth. The concentration of calcium in tissues is variable and in cells, it is found mainly in the endoplasmic reticulum and mitochondria. ${ }^{14}$

Cadmium is a non-essential and highly toxic metal. The main anthropic sources are electroplating, mining, pigment manufacturing, alkaline batteries, and metallurgical activities. ${ }^{15}$ Prolonged exposure to this element and its salts can cause kidney failure, anemia, cardiovascular disease, growth impairment, and loss of taste and smell. For these reasons, environmental regulatory agencies define severe limitations on the maximum concentration of cadmium in 
natural water bodies, as well as the maximum concentration allowed for the discharge of wastewater. ${ }^{16}$

Copper is considered an essential trace element for human health. It is found in all fluids and various tissues, being of vital importance for many metabolic processes. ${ }^{17}$ However, an excess of this element is toxic due to its affinity with the sulfhydryl (-SH) groups of several proteins and enzymes, being associated with diseases such as Wilson's disease, epilepsy, melanoma, and rheumatoid arthritis, as well as loss of taste..$^{17,18}$

Exploration and production of oil and natural gas, in onshore or offshore platforms produce wastes and effluents, among which produced water stands out, which is extracted together with oil and the gas. This residue consists of the formation water naturally present in the geological origin of the oil reservoir, and injected water into the reservoir to increase the productivity of the well. ${ }^{19}$ Produced water represents the chief effluent for companies involved in the oil sector. ${ }^{20}$

Several metal ions and anions are found in produced waters. Their amount depends on the producing field, particularly with regard to age and geological formation. ${ }^{21}$ The concentration of most metal ions is usually much above the levels found in seawater in an uncontaminated environment, ${ }^{22}$ even more than a thousand times higher. The toxic and harmful effects of the produced waters are due to the nature and concentration of the various components present, ${ }^{23}$ e.g., cadmium, arsenic, copper, lead and mercury.

In recent years, several ternary oxides of the $\mathrm{SiO}_{2} / \mathrm{M}_{\mathrm{x}} \mathrm{O}_{\mathrm{y}} / \mathrm{N}_{\mathrm{z}} \mathrm{O}_{\mathrm{w}}$ type have been synthesized by the sol-gel process, among them $\mathrm{ZnO} / \mathrm{TiO}_{2} / \mathrm{SiO}_{2},{ }^{24} \mathrm{Re}_{2} \mathrm{O}_{7} / \mathrm{SiO}_{2} / \mathrm{Al}_{2} \mathrm{O}_{3},{ }^{25}$ $\mathrm{SiO}_{2} / \mathrm{Nb}_{2} \mathrm{O}_{5} / \mathrm{ZnO},{ }^{26} \mathrm{SiO}_{2} / \mathrm{Al}_{2} \mathrm{O}_{3} / \mathrm{Nb}_{2} \mathrm{O}_{5}$ and $\mathrm{SiO}_{2} / \mathrm{Al}_{2} \mathrm{O}_{3} / \mathrm{TiO}_{2},{ }^{27}$ $\mathrm{SiO}_{2} / \mathrm{TiO}_{2} / \mathrm{Sb}_{2} \mathrm{O}_{5},{ }^{28}$ and $\mathrm{SiO}_{2} / \mathrm{Al}_{2} \mathrm{O}_{3} / \mathrm{ZrO}_{2} \cdot{ }^{29}$ These materials present potential application: $(i)$ as molecular adsorbents $\left(\mathrm{SiO}_{2} / \mathrm{Al}_{2} \mathrm{O}_{3} / \mathrm{Nb}_{2} \mathrm{O}_{5}\right.$ and $\left.\mathrm{SiO}_{2} / \mathrm{Al}_{2} \mathrm{O}_{3} / \mathrm{TiO}_{2}\right){ }^{27}$ (ii) in metal ion pre-concentration systems $\left(\mathrm{SiO}_{2} / \mathrm{Nb}_{2} \mathrm{O}_{5} / \mathrm{ZnO},{ }^{26}\right.$ $\mathrm{SiO}_{2} / \mathrm{Al}_{2} \mathrm{O}_{3} / \mathrm{TiO}_{2},{ }^{30}$ and $\left.\mathrm{SiO}_{2} / \mathrm{Al}_{2} \mathrm{O}_{3} / \mathrm{SnO}_{2}\right) ;^{31,32}$ (iii) photocatalysis $\left(\mathrm{B}_{2} \mathrm{O}_{3} / \mathrm{SiO}_{2} / \mathrm{TiO}_{2}\right){ }^{33}$ (iv) electrocatalysis $\left(\mathrm{SnO}_{2} / \mathrm{IrO}_{2} / \mathrm{Ta}_{2} \mathrm{O}_{5}\right){ }^{34}(v)$ adsorption of effluent dyes $\left(\mathrm{SiO}_{2} / \mathrm{Al}_{2} \mathrm{O}_{3} / \mathrm{TiO}_{2}\right) .{ }^{35}$

The use of these ternary oxides in the petroleum area is unprecedented and has several promising applications ranging from the control of inorganic contaminants in oil and oil products to the treatment of water effluents in refineries and produced waters in onshore and offshore platforms. Thus, in this work, we describe a detailed study on adsorption of standard $\mathrm{Ca}^{\mathrm{II}}, \mathrm{Cd}^{\mathrm{II}}$, and $\mathrm{Cu}^{\mathrm{II}}$ and a real sample of produced water by a silicon-aluminumzirconium ternary oxide $\left(\mathrm{SiO}_{2} / \mathrm{Al}_{2} \mathrm{O}_{3} / \mathrm{ZrO}_{2}\right)$ prepared by the sol-gel process. This study stands out, in the future, the use of ternary adsorbents in the oil industry, where $\mathrm{ZrO}_{2}$ has more basic properties than $\mathrm{Al}_{2} \mathrm{O}_{3}$ and $\mathrm{SiO}_{2}$, which allows opportunity to adsorb a greater range of ions.

\section{Experimental}

Properties of the $\mathrm{SiO}_{2} / \mathrm{Al}_{2} \mathrm{O}_{3} / \mathrm{ZrO}_{2}$ ternary oxide

The detailed study of synthesis and characterization of $\mathrm{SiO}_{2} / \mathrm{Al}_{2} \mathrm{O}_{3} / \mathrm{ZrO}_{2}$ ternary oxide ( $\left.\mathrm{SiAlZr}-\mathrm{A}\right)$ has been published elsewhere. ${ }^{29}$ In this work, the SiAlZr-A material will simply be called SiAlZr.

The main properties of the SiAlZr ternary oxide are: (i) chemical composition: 34.9 wt. $\%$ of $\mathrm{ZrO}_{2}$ and $4.7 \mathrm{wt} . \%$ of $\mathrm{Al}_{2} \mathrm{O}_{3}$ in the silica matrix; (ii) Brunauer-Emmett-Teller (BET) specific surface area $\left(\mathrm{S}_{\mathrm{BET}}\right), 349 \mathrm{~m}^{2} \mathrm{~g}^{-1}$; (iii) mean average pore size, $33.4 \AA$, according to the Barrett-JoynerHalenda $(\mathrm{BJH})$ method, indicating that this ternary oxide is predominantly mesoporous; (iv) mean pore volume, $0.021 \mathrm{~cm}^{-3} \mathrm{~g}^{-1}$. According to X-ray photoelectron spectroscopy (XPS) and scanning electron microscopy with energy dispersive spectroscopy (SEM-EDS) data, the synthesized materials are homogeneous. This material presents good thermal stability according to thermogravimetric-differential thermal analysis (TGA-DTA) data. From X-ray diffraction (XRD) analysis, crystalline phases in the ternary oxide were found only after heating at $1073 \mathrm{~K} . \mathrm{CO}_{2}$-TPD (temperature programmed desorption) showed the presence of weak and strong basic sites for the material, and $\mathrm{NH}_{3}$-TPD pointed to the presence of weak acid sites only, but pyridine adsorption detected both Lewis (LAS) and Brønsted (BAS) acidic sites. Due to these characteristics, ${ }^{29}$ the material is promising for the application described in this paper.

\section{Preparation of solutions}

\section{Cul}

$1.2000 \mathrm{~g}$ of high purity metallic copper metal (SigmaAldrich, Saint Louis, Missouri, USA; > 99.995\%) was weighed on an analytical balance. The metal was transferred to a beaker and $20.0 \mathrm{~mL}$ of concentrated nitric acid were added. The resulting solution was evaporated to dryness, followed by dissolution in ultrapure water. After cooling to $298.15 \mathrm{~K}$, the solution was quantitatively transferred to a $1000 \mathrm{~mL}$ volumetric flask and the volume was made up with ultrapure water.

\section{Cd"}

$1.6465 \mathrm{~g}$ of $\mathrm{Cd}^{\mathrm{II}}$ nitrate tetrahydrate (Merck KGaA, Darmstadt, Germany; $\left.\mathrm{Cd}\left(\mathrm{NO}_{3}\right)_{2} \cdot 4 \mathrm{H}_{2} \mathrm{O}\right)$ were weighed on an analytical balance. This salt was transferred quantitatively 
to a $1000 \mathrm{~mL}$ volumetric flask and the volume was made up with ultrapure water.

Ca"

$2.9968 \mathrm{~g}$ of calcium carbonate (Vetec, Duque de Caxias, Rio de Janeiro, Brazil; $\mathrm{CaCO}_{3}$ ), a primary standard, were weighed on an analytical balance. This reagent was transferred to a beaker and $20.0 \mathrm{~mL}$ of $4 \mathrm{~mol} \mathrm{~L}^{-1} \mathrm{HCl}$ were added to dissolve it. The resulting solution was heated for the total expulsion of the carbon dioxide $\left(\mathrm{CO}_{2}\right)$. After cooling to $298.15 \mathrm{~K}$, the solution was quantitatively transferred to a $1000 \mathrm{~mL}$ volumetric flask and the volume was made up with ultrapure water.

\section{Buffer solution}

The following buffer systems were prepared using ultrapure water: potassium sulfate (Vetec, Duque de Caxias, Rio de Janeiro, Brazil)/potassium hydrogenosulfate (SigmaAldrich, Saint Louis, Missouri, USA) (pH 2), sodium formate (Vetec, Duque de Caxias, Rio de Janeiro, Brazil)/formic acid (Vetec, Duque de Caxias, Rio de Janeiro, Brazil) (pH 3), acetic acid (Vetec, Duque de Caxias, Rio de Janeiro, Brazil)/ sodium acetate (Vetec, Duque de Caxias, Rio de Janeiro, Brazil) (pH 4 and 5) and citric acid (Sigma-Aldrich, Saint Louis, Missouri, USA)/sodium citrate (Sigma-Aldrich, Saint Louis, Missouri, USA) (pH 6). ${ }^{36}$

\section{Sample of produced water}

The real sample chosen for the application of this material was a produced water from the Almirante Barroso Maritime Terminal (TEBA), located in São Sebastião (São Paulo State, Brazil), provided for this study by the Applied Electrochemistry Laboratory of the Metallurgical and Materials Engineering Program (PEMM-COPPE-UFRJ). Its main physico-chemical properties are $\mathrm{pH}, 7.4$; electrical conductivity, $7.86 \mu \mathrm{S} \mathrm{cm}^{-1}$; oils and waxes, $10 \mathrm{mg} \mathrm{L}^{-1}$. Its chemical characterization is shown in Table $1 .{ }^{37}$

\section{Adsorption assays}

\section{At different $\mathrm{pH}$}

The $\mathrm{pH}$ of the solution exerts a profound influence on adsorption process, since $\mathrm{pH}$ variations impact not only on protonation of functional groups of adsorbent, but also on the degree of ionization of the metal ions. ${ }^{38}$ The $\mathrm{pH}$ range of assays was chosen between 2-6 in order to avoid the precipitation of ions as metal hydroxides, which occurs at a $\mathrm{pH}$ above $6 . .^{38,39}$ The increase in adsorption capacity at $\mathrm{pH}>6$ may result from a combination of adsorption and precipitation on the surface of the adsorbent. ${ }^{40}$

The adsorption isotherms for $\mathrm{Ca}^{\mathrm{II}}, \mathrm{Cd}^{\mathrm{II}}$ and $\mathrm{Cu}^{\mathrm{II}}$ ions in aqueous medium were performed by batch technique. In this study, the concentration of the metal ion was firstly kept constant and the $\mathrm{pH}$ was varied. For each metallic ion, five aliquots of the adsorbent were weighed, each containing approximately $100 \mathrm{mg}$. The aliquots were transferred to flasks containing $30 \mathrm{~mL}$ of a solution consisting of $5 \mathrm{~mL}$ of a specific buffer solution for each $\mathrm{pH}$ (ranging from $\mathrm{pH} 2$ to 6) and $25 \mathrm{~mL}$ of the metal ion solution. The flasks were placed in a thermostatic bath (Nova Ética Dubnoff) and stirred for $24 \mathrm{~h}$ at a controlled temperature of $298.16 \mathrm{~K}$.

After the experiments, the system was transferred to Falcon-type tubes and centrifuged (Biomedics 1970). The supernatant was analyzed by atomic absorption spectrometry (Shimadzu AA6800) with an automatic sampler and an air-acetylene flame. The amount of metal ion adsorbed on the adsorbent surface was determined by the difference between the amount present in the supernatant and the amount initially present in the original solution.

The equilibrium time is of fundamental importance to guarantee the minimum time necessary to promote an effective contact between the adsorbent and the metal ion solution. For this reason, the experiments were run for $24 \mathrm{~h}$. As in most of studies involving metal ions adsorption, temperature was set up at $298.16 \mathrm{~K}$.

\section{At different metal ion concentration}

In these experiments, the $\mathrm{pH}$ was maintained constant, and the concentration of the metal ions was varied by diluting the standard solution with the appropriate amount of ultrapure water. The batch procedure and the analytical protocol follow the same procedures described earlier.

The experimental data obtained from this assay were fitted to non-linear models of Langmuir, Freundlich, single, and dual-site hybrid Langmuir-Freundlich. ${ }^{26}$ The

Table 1. Average concentration of inorganic components in the produced water ${ }^{37}$

\begin{tabular}{lccccc}
\hline Ion & Concentration $/\left(\mathrm{mg} \mathrm{L}^{-1}\right)$ & Ion & Concentration $/\left(\mathrm{mg} \mathrm{L}^{-1}\right)$ & Ion & Concentration / $\left(\mathrm{mg} \mathrm{L}^{-1}\right)$ \\
\hline $\mathrm{Cl}^{\mathrm{I}}$ & 29,830 & $\mathrm{~K}^{\mathrm{I}}$ & 281 & $\mathrm{~B}^{\mathrm{III}}$ & 35 \\
$\mathrm{Na}^{\mathrm{I}}$ & 19,410 & $\mathrm{Sr}^{\mathrm{II}}$ & 150 & $\mathrm{Cr}^{\mathrm{III}}$ & 7.7 \\
$\mathrm{Ca}^{\mathrm{II}}$ & 1,150 & $\mathrm{~S}^{\mathrm{II}}$ & 86 & $\mathrm{SO}_{4}{ }^{\mathrm{II}}$ & 6.0 \\
$\mathrm{Mg}^{\mathrm{II}}$ & 520 & $\mathrm{Ba}^{\mathrm{II}}$ & 85 & $\mathrm{Fe}^{\mathrm{III}}$ & 5.9 \\
\hline
\end{tabular}


Langmuir model is described by equation 1 , where $\mathrm{Q}_{\mathrm{e}}$ is the amount adsorbed $\left(\mathrm{mg} \mathrm{g}^{-1}\right) ; \mathrm{C}_{\mathrm{eq}}$ is the concentration of the adsorbate in the solution at equilibrium $\left(\mathrm{mg} \mathrm{L}^{-1}\right)$; $\mathrm{b}$ is the maximum adsorption capacity $\left(\mathrm{mg} \mathrm{g}^{-1}\right)$ and $\mathrm{K}_{\mathrm{L}}$ refers to the equilibrium constant of Langmuir $\left(\mathrm{L} \mathrm{mg}^{-1}\right)$, which is related to the energy of adsorption. This model predicts a fixed number of energetically homogeneous sites, in which the interaction with the adsorbate occurs, but there are no interactions between the adsorbed species. Therefore, when the saturation occurs, a monolayer of the adsorbate is formed on the surface of the adsorbent. ${ }^{41,42}$ The separation factor $\left(\mathrm{R}_{\mathrm{L}}\right)$ is a dimensionless constant that can express essential features of the Langmuir isotherm and is defined by the equation 2 , where $\mathrm{C}_{0}\left(\mathrm{mg} \mathrm{L}^{-1}\right)$ is the initial adsorbate concentration and $\mathrm{K}_{\mathrm{L}}$ is the Langmuir constant. The value of $R_{L}$ indicates the shape of the isotherms to be either unfavorable $\left(R_{L}>1\right)$, linear $\left(R_{L}=1\right)$, favorable $\left(0<\mathrm{R}_{\mathrm{L}}<1\right)$ or irreversible $\left(\mathrm{R}_{\mathrm{L}}=0\right){ }^{43}$

$Q_{e}=\frac{K_{L} \times b \times C_{e q}}{\left(1+K_{L} \times C_{e q}\right)}$

$\mathrm{R}_{\mathrm{L}}=\frac{1}{\left(1+\mathrm{K}_{\mathrm{L}} \times \mathrm{C}_{0}\right)}$

The Freundlich model is represented by equation 3, where $\mathrm{K}_{\mathrm{F}}$ refers to the equilibrium constant of Freundlich $\left(\mathrm{mg} \mathrm{g}^{-1}\right)\left(\mathrm{L} \mathrm{g}^{-1}\right)$ and $\mathrm{n}$ is the empirical constant of Freundlich (dimensionless), referring to the heterogeneity of adsorption sites. According to this model, the amount of the analyte adsorbed is proportional to its concentration in the solute. Thus, it assumes that, theoretically, the adsorption is infinite. Also, it predicts that the adsorption may occur via multiple layers rather than a monolayer. ${ }^{41,42}$

$\mathrm{Q}_{\mathrm{e}}=\mathrm{K}_{\mathrm{F}} \times \mathrm{C}_{\mathrm{eq}}{ }^{1 / \mathrm{n}}$

Single-site Langmuir-Freundlich model is originated from the combination of Langmuir and Freundlich models, and it is represented by equation 4 . This model assumes the existence of energetically homogeneous sites. When the adsorbate is in low concentration, it is reduced to the Freundlich model, while when in high concentration, it assumes a monolayer adsorption characteristic of the Langmuir model. On the other hand, the dual-site Langmuir-Freundlich model, described by equation 5 , assumes the existence of adsorption sites with different energies. According to this model, the adsorbate interacts with sites with low energy when it is at low concentrations, while, at high concentrations, interacts also with high energy. ${ }^{41,42}$

$$
\begin{aligned}
& \mathrm{Q}_{\mathrm{e}}=\frac{\mathrm{b} \times\left(\mathrm{K} \times \mathrm{C}_{\text {eq }}\right)^{\mathrm{n}}}{1+\left(\mathrm{K} \times \mathrm{C}_{\text {eq }}\right)^{\mathrm{n}}} \\
& \mathrm{Q}_{\mathrm{e}}=\frac{\mathrm{b}_{1} \times\left(\mathrm{K}_{1} \times \mathrm{C}_{\text {eq }}\right)^{\mathrm{n}_{1}}}{1+\left(\mathrm{K}_{1} \times \mathrm{C}_{\mathrm{eq}}\right)^{\mathrm{n}_{1}}}+\frac{\mathrm{b}_{2} \times\left(\mathrm{K}_{2} \times \mathrm{C}_{\mathrm{eq}}\right)^{\mathrm{n}_{2}}}{1+\left(\mathrm{K}_{2} \times \mathrm{C}_{\mathrm{eq}}\right)^{\mathrm{n}_{2}}}
\end{aligned}
$$

In equations 4 and $5, \mathrm{~K}$ is the equilibrium constant $\left(\mathrm{L} \mathrm{mg}^{-1}\right)$ representing adsorbent-adsorbate affinity, and the subscript numbers 1 and 2 refer to the binding sites.

\section{Tests with a real sample of produced water}

Approximately $300 \mathrm{mg}$ of the adsorbent were weighed and transferred to flasks containing $90 \mathrm{~mL}$ of a solution consisting of $15 \mathrm{~mL}$ of the buffer solution (pH 5 or 6) and $75 \mathrm{~mL}$ of the produced water. The experimental conditions were the same described earlier. Each sample was weighed before and after the adsorption assay. The adsorbent material after the test was sent for X-ray fluorescence by wavelength dispersion (WDXRF) analysis (AxiosMax model from Panalytical). Samples were prepared by melting a $1: 10 \mathrm{~m} / \mathrm{m}$ dry sample to flux ratio at $1323.15 \mathrm{~K}$ in a Vulcan machine. The flux was composed of lithium borates (66 wt. $\% \mathrm{Li}_{2} \mathrm{~B}_{4} \mathrm{O}_{7}$, and 34 wt. $\% \mathrm{LiBO}_{2}$ ). The results were expressed in wt.\% as oxides and normalized to $100 \mathrm{wt} . \%$. Loss by calcination was determined by roasting weighed samples in a furnace at $1273.15 \mathrm{~K}$ for $16 \mathrm{~h}$. After cooling, they were weighed on an analytical balance.

\section{Results and Discussion}

\section{Effect of $\mathrm{pH}$}

The adsorption isotherms are a useful way to study the metal ion removal capacity by different solid adsorbents. The adsorption isotherms allow the development of the adsorption curve equations, obtained by the mass balance after performing batch tests varying the $\mathrm{pH}$ and concentration of each ion studied $\left(\mathrm{Ca}^{\mathrm{II}}, \mathrm{Cd}^{\mathrm{II}}\right.$ and $\mathrm{Cu}^{\mathrm{II}}$ ions).

The amount of metal ion adsorbed on the adsorbent surface was determined by the difference between the amount present after the batch and the initial amount. The calculation of adsorption equilibrium in batch assays was evaluated using equation 6 :

$\mathrm{q}_{\mathrm{e}}=\frac{\left(\mathrm{C}_{\mathrm{o}}-\mathrm{C}_{\mathrm{e}}\right) \mathrm{V}}{\mathrm{M}}$

where $\mathrm{q}_{\mathrm{e}}$ is the amount of solute adsorbed per unit mass of adsorbent, in equilibrium $\left(\mathrm{mg} \mathrm{g}^{-1}\right), \mathrm{C}_{\mathrm{o}}$ is the initial concentration of adsorbate in the liquid phase $\left(\mathrm{mg} \mathrm{L}^{-1}\right)$, 
$\mathrm{C}_{\mathrm{e}}$ is the final concentration of adsorbate or equilibrium concentration in the liquid phase $\left(\mathrm{mg} \mathrm{L}^{-1}\right), \mathrm{V}$ is the volume of sample used (L) and $\mathrm{M}$ is mass of the adsorbent material (g). ${ }^{44}$

Initially, the best $\mathrm{pH}$ was chosen for the adsorption of each ion. For this purpose, the adsorption isotherms were made, in which the adsorbed quantities $\left(Q_{e}\right)$ of $\mathrm{Ca}^{\mathrm{II}}, \mathrm{Cd}^{\mathrm{II}}$, and $\mathrm{Cu}^{\mathrm{II}}$, were plotted on the ordinate axis, while the abscissa axis is plotted the $\mathrm{pH}$ of the solution. The isotherms are represented in Figure 1. Through this graphical analysis, it was possible to select the $\mathrm{pH}$ that maximizes the adsorption of each ion. For $\mathrm{Ca}^{\mathrm{II}}$ and $\mathrm{Cd}^{\mathrm{II}}$ ions, the highest efficiency was found at $\mathrm{pH} 6$, while for $\mathrm{Cu}^{\mathrm{II}}$ ions the best result was at $\mathrm{pH}$ 5. The $\mathrm{pH}$ assays show that the factors that affect the adsorption characteristics of adsorbents are: (i) the competition of $\mathrm{H}^{+}$ions with metal ions for adsorption at low $\mathrm{pH}$; (ii) maximum adsorption at pH 5-6; (iii) the precipitation of hydroxylated species in adsorbents at $\mathrm{pH}$ above $6 .^{40}$ The studies were not carried out at $\mathrm{pH}<2$, as it occurs the protonation of the silanol group of matrix generating the $\mathrm{SiOH}_{2}{ }^{+}$species, leading to the dissolution of the SiAlZr material. ${ }^{45}$

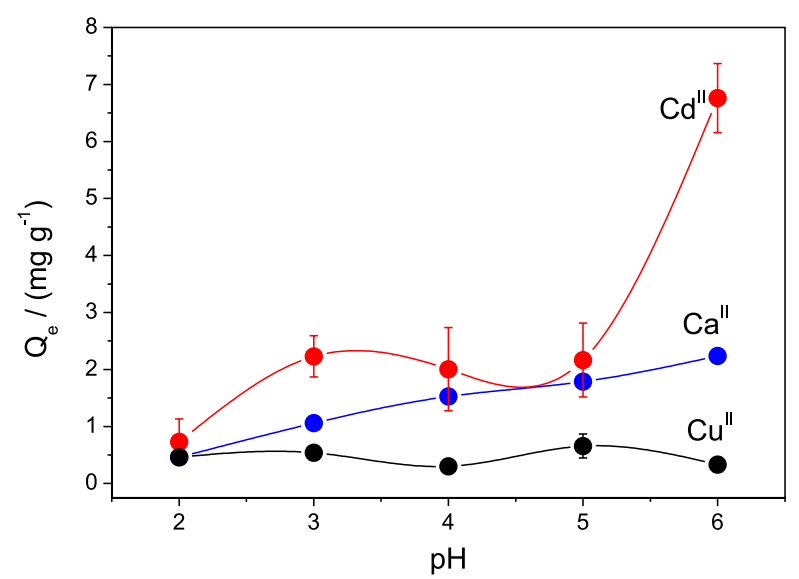

Figure 1. Adsorption of $\mathrm{Ca}^{\mathrm{II}}, \mathrm{Cd}^{\mathrm{II}}$ and $\mathrm{Cu}^{\mathrm{II}}$ on the $\mathrm{SiO}_{2} / \mathrm{Al}_{2} \mathrm{O}_{3} / \mathrm{ZrO}_{2}$ adsorbent material $(24 \mathrm{~h}, 298.16 \mathrm{~K})$.

Although there is apparently a smaller amount of $\mathrm{Cu}^{\mathrm{II}}$ in solution at $\mathrm{pH} 6$, this does not mean a greater adsorption, instead, at this $\mathrm{pH}$ copper precipitated as $\mathrm{Cu}(\mathrm{OH})_{2}$, which reduced the amount available for adsorption. This can be attributed to additional restrictions on the mass transfer imposed by the formation/deposition of suspended solids. For this reason, this point was disregarded in the analysis of this ion. This problem did not take place in the case of $\mathrm{Cd}^{\mathrm{II}}$ and $\mathrm{Ca}^{\mathrm{II}}$ as their hydroxides only precipitate at higher $\mathrm{pH} .{ }^{46}$

\section{Effect of the initial concentration of the metal ion}

Figure 2 shows the isotherms for $\mathrm{Ca}^{\mathrm{II}}, \mathrm{Cd}^{\mathrm{II}}$ and $\mathrm{Cu}^{\mathrm{II}}$, in which the quantities of each ion adsorbed per unit of adsorbent mass $\left(\mathrm{Q}_{\mathrm{e}}\right)$ are plotted on the ordinate axis, while the equilibrium concentration of the metal ions in solution $\left(\mathrm{C}_{\mathrm{eq}}\right)$ is plotted on the abscissa.

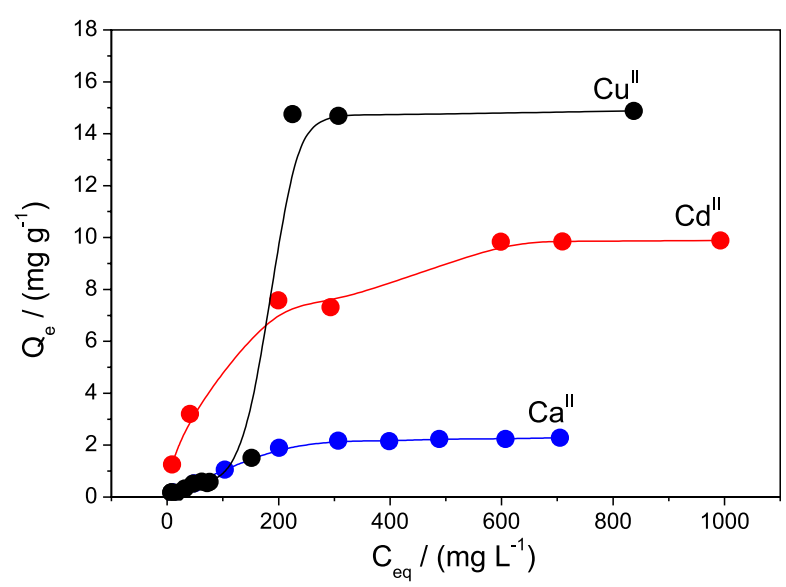

Figure 2. Adsorption isotherms of $\mathrm{Ca}^{\mathrm{II}}, \mathrm{Cd}^{\mathrm{II}}$ and $\mathrm{Cu}^{\mathrm{II}}$ on the $\mathrm{SiO}_{2} / \mathrm{Al}_{2} \mathrm{O}_{3} / \mathrm{ZrO}_{2}$ adsorbent material $(24 \mathrm{~h}, 298.16 \mathrm{~K})$.

With the data resulting from the batch test, the parameters could be estimated by adjusting theoretical curves to the isotherm data. This adaptation was performed based on the non-linear models of Freundlich, Langmuir, single and dual-site hybrid Langmuir-Freundlich equations. The most appropriate model was selected by comparing the values of the correlation coefficients $\left(\mathrm{R}^{2}\right)$, the root mean square error (RMSE), and the theoretical maximum adsorption capacity (b) close to the experimental one for the $\mathrm{SiO}_{2} / \mathrm{Al}_{2} \mathrm{O}_{3} / \mathrm{ZrO}_{2}$ adsorbent and each ion studied. The adjusted models can be found in Supplementary Information, while the calculated parameters for each model are shown in Table 2.

The experimental maximum adsorption capacity of the ions was $2.28 \mathrm{mg} \mathrm{g}^{-1}$ for $\mathrm{Ca}^{\mathrm{II}}, 9.89 \mathrm{mg} \mathrm{g}^{-1}$ for $\mathrm{Cd}^{\mathrm{II}}$, and $14.88 \mathrm{mg} \mathrm{g}^{-1}$ for $\mathrm{Cu}^{\mathrm{II}}$. Therefore, for adsorption, the best adjustments were obtained by using both the single and dual-site Langmuir-Freundlich models for all metal ions. The dual-site Langmuir-Freundlich model predicts the existence of two adsorption sites with different affinities towards the analyte, determined by the parameters $\mathrm{K}_{1}$ and $\mathrm{K}_{2}\left(\mathrm{~L} \mathrm{mg}^{-1}\right)$. However, it can be observed that approximately $80 \%$ of the $\mathrm{Ca}^{\mathrm{II}}$ adsorption and around $95 \%$ of the $\mathrm{Cd}^{\mathrm{II}}$ and $\mathrm{Cu}^{\mathrm{II}}$ adsorption occur in the lower affinity sites $\left(\mathrm{K}_{1}\right)$. Therefore, this explains the goodness of the fit provided by the single-site Langmuir-Freundlich model as well. ${ }^{26}$ Beyond that, as shown in Table $2, \mathrm{R}_{\mathrm{L}}$ values regarding the Langmuir features for all ions studied are in the range of $0-1$, which indicates their favorable adsorption on $\mathrm{SiO}_{2} / \mathrm{Al}_{2} \mathrm{O}_{3} / \mathrm{ZrO}_{2}$ adsorbent. It is important to mention that the $\mathrm{R}_{\mathrm{L}}$ values in Table 2 were calculated using the first initial concentrations of each ion, and lower $R_{L}$ values are 
Table 2. Isotherm parameters obtained from the Langmuir, Freundlich, single and dual-site Langmuir-Freundlich models applied to the $\mathrm{Ca}^{\mathrm{II}}, \mathrm{Cd}^{\mathrm{II}}$ and $\mathrm{Cu}^{\mathrm{II}}$ adsorption by $\mathrm{SiO}_{2} / \mathrm{Al}_{2} \mathrm{O}_{3} / \mathrm{ZrO}_{2}$

\begin{tabular}{|c|c|c|c|c|c|c|c|c|c|c|c|c|}
\hline & & $\begin{array}{c}\mathrm{b}_{1} / \\
\left(\mathrm{mg} \mathrm{g}^{-1}\right)\end{array}$ & $\begin{array}{c}\mathrm{b}_{2} / \\
\left(\mathrm{mg} \mathrm{g}^{-1}\right)\end{array}$ & $\begin{array}{c}\mathrm{K}_{\mathrm{L}} / \\
\left(\mathrm{L} \mathrm{mg}^{-1}\right)\end{array}$ & $\mathrm{R}_{\mathrm{L}}$ & $\begin{array}{c}\mathrm{K}_{\mathrm{F}} / \\
\left(\mathrm{mg} \mathrm{g}^{-1}\right)\left(\mathrm{L} \mathrm{g}^{-1}\right)\end{array}$ & $\begin{array}{c}\mathrm{K}_{1} / \\
\left(\mathrm{L} \mathrm{mg}^{-1}\right)\end{array}$ & $\begin{array}{c}\mathrm{K}_{2} / \\
\left(\mathrm{L} \mathrm{mg}^{-1}\right)\end{array}$ & $\mathrm{n}_{1}$ & $\mathrm{n}_{2}$ & $\mathrm{R}^{2}$ & RMSE \\
\hline \multirow{4}{*}{$\mathrm{Ca}$} & Langmuir & 2.88 & & 0.0071 & 0.092 & & & & & & 0.9632 & 0.1688 \\
\hline & Freundlich & & & & & 0.1753 & & & 0.408 & & 0.8873 & 0.2954 \\
\hline & Lan-Fre 1S & 2.34 & & & & & 0.0099 & & 1.941 & & 0.9887 & 0.1011 \\
\hline & Lan-Fre $2 \mathrm{~S}$ & 1.85 & 0.41 & & & & 0.0088 & 0.0991 & 3.987 & 2.011 & 0.9985 & 0.0458 \\
\hline \multirow{4}{*}{$\mathrm{Cd}$} & Langmuir & 11.06 & & 0.0097 & 0.101 & & & & & & 0.9832 & 0.4930 \\
\hline & Freundlich & & & & & 1.0690 & & & 0.337 & & 0.9418 & 0.9176 \\
\hline & Lan-Fre 1S & 11.95 & & & & & 0.0079 & & 0.846 & & 0.9858 & 0.5074 \\
\hline & Lan-Fre $2 \mathrm{~S}$ & 11.11 & 0.43 & & & & 0.0078 & 1.2740 & 0.946 & 10.150 & 0.9861 & 1.0040 \\
\hline \multirow{4}{*}{$\mathrm{Cu}$} & Langmuir & 27.71 & & 0.0019 & 0.116 & & & & & & 0.7403 & 3.5750 \\
\hline & Freundlich & & & & & 0.1626 & & & 0.698 & & 0.6767 & 3.9890 \\
\hline & Lan-Fre 1S & 14.79 & & & & & 0.0060 & & 21.100 & & 0.9967 & 0.4262 \\
\hline & Lan-Fre $2 S$ & 14.28 & 0.61 & & & & 0.0056 & 0.0440 & 16.010 & 1.867 & 0.9998 & 0.1475 \\
\hline
\end{tabular}

$\mathrm{b}_{1}$ and $\mathrm{b}_{2}$ : maximum adsorption capacity; $\mathrm{K}_{\mathrm{L}}$ : Langmuir equilibrium constant; $\mathrm{R}_{\mathrm{L}}$ : separation factor; $\mathrm{K}_{\mathrm{F}}$ : Freundlich equilibrium constant; $\mathrm{K}_{1}$ and $\mathrm{K}_{2}$ : equilibrium constant; n: Freundlich empiric constant; RMSE: root mean square error; Lan-Fre 1S: Langmuir-Freundlich one site; Lan-Fre 2S: LangmuirFreundlich two sites.

obtained in higher initial concentrations. Once the degree of favorability is generally related to the irreversibility of the system and it tends towards zero as the $\mathrm{C}_{0}$ approaches equilibrium, it can be assumed that the ions adsorption on $\mathrm{SiO}_{2} / \mathrm{Al}_{2} \mathrm{O}_{3} / \mathrm{ZrO}_{2}$ adsorbent becomes more suitable at high concentrations. ${ }^{47}$

The surface sites for the ions adsorption are represented by $\mathrm{Si}-\mathrm{OH}, \mathrm{Al}-\mathrm{OH}$ and $\mathrm{Zr}-\mathrm{OH}$. Considering that the $\mathrm{Al}_{2} \mathrm{O}_{3}$ percentage in the material is very low, it is likely that the adsorptions occur mainly in the $\mathrm{Si}-\mathrm{OH}$ and $\mathrm{Zr}-\mathrm{OH}$ sites. Additionally, since zirconium oxide has a more basic character than silanols, $\mathrm{Zr}-\mathrm{OH}$ might be considered the binding site responsible for the most metal ions adsorption. ${ }^{26,29}$

Table 3 shows the comparison of adsorptive capacities between the material studied and others found in the literature, at each optimum $\mathrm{pH}$. Analyzing these data, our adsorbent is one of the least effective, but this comparison is not trivial, as the studies are carried out under different conditions. Another important detail is that our study was introductory and that there was no chemical modification over the adsorbent surface, as occurred in other studies, these alterations can increase the specificity for a determined ion, causing an increase in its adsorptive capacity. ${ }^{8}$ In future works this chemical modification will be studied.

\section{Application in a real sample of produced water}

In this case, two different $\mathrm{pH}$ were studied to better assess the influence of the acidity. Table 4 shows the amount of adsorbed ions in the batch assays using the produced water as a real sample. This table shows the mass composition of each chemical species according to WDXRF data, including the components of the $\mathrm{SiO}_{2} / \mathrm{Al}_{2} \mathrm{O}_{3} /$ $\mathrm{ZrO}_{2}$ adsorbent.

As expected, the introduction of species from the sample of produced water reduced the original levels of $\mathrm{Si}, \mathrm{Al}$ and $\mathrm{Zr}$. This effect decreased in the order $\mathrm{Al}>\mathrm{Zr}$ $>$ Si. It was not possible to define whether phosphorus entry occurred via adsorption at exchange sites or is simply an effect of the deposition of metal phosphates precipitates (such as $\mathrm{FePO}_{4}$ ) on the adsorbent surface at the $\mathrm{pH}$ of the experiments. However, the significant increase in the amount of chloride in the adsorbent after the tests suggests the insertion of foreign anions in anion exchange sites (basic $\left.\mathrm{OH}^{-}\right)$since the metals detected in Table 4 do not form insoluble chlorides ${ }^{53}$ This same effect was noticed, although in a lower degree, in the case of the sulfate ion. The increase in the percentage of calcium (and magnesium) after the experiment at $\mathrm{pH} 6$ correlates with the higher adsorption at that $\mathrm{pH}$ in assays with $\mathrm{Ca}^{\mathrm{II}}$ standard solution. The adsorption of other cations, especially sodium ion (due to its high concentration in the produced water) also increased with the increase in $\mathrm{pH}$, reflecting the exchange on cationic sites $\left(\mathrm{O}-\mathrm{H}^{+} \rightarrow \mathrm{O}-\mathrm{Na}^{+}\right)$. This suggests that the prepared materials present acidic and basic exchange sites, which is a very useful property for treating effluents containing a variety of components such as produced waters. 
Table 3. Comparison with the literature on adsorptive capacity

\begin{tabular}{|c|c|c|c|c|c|}
\hline & Adsorbent & $\begin{array}{l}\text { Metal adsorption } \\
\text { capacity / }\left(\mathrm{mg} \mathrm{g}^{-1}\right)\end{array}$ & Buffer solution & Reference & Description \\
\hline \multirow{2}{*}{$\mathrm{Ca}^{\mathrm{II}}$} & [NPSi-SH] & 4.01 & $\mathrm{pH} 7$ & 5 & $\begin{array}{l}\text { nanoporous silica (NP) synthesized and } \\
\text { modified with thiol moiety [NPSi-SH] }\end{array}$ \\
\hline & $\mathrm{SiO}_{2} / \mathrm{Al}_{2} \mathrm{O}_{3} / \mathrm{ZrO}_{2}$ & 2.28 & pH 6 & this work & $\begin{array}{l}\text { ternary oxide silica-alumina-zirconia } \\
\qquad\left(\mathrm{SiO}_{2} / \mathrm{Al}_{2} \mathrm{O}_{3} / \mathrm{ZrO}_{2}\right)\end{array}$ \\
\hline \multirow{9}{*}{$\mathrm{Cd}^{\mathrm{II}}$} & [NPSi-SH] & 42.16 & $\begin{array}{l}0.1 \mathrm{~mol} \mathrm{~L}^{-1} \text { sodium } \\
\text { acetate }\end{array}$ & 5 & $\begin{array}{l}\text { nanoporous silica (NP) synthesized and } \\
\text { modified with thiol moiety [NPSi-SH] }\end{array}$ \\
\hline & nano-CI & 95.55 & $\mathrm{pH} 7$ & 9 & nano-chitosan coating nano-iron oxide \\
\hline & nano-CIC & 202.34 & pH 6 & 9 & $\begin{array}{l}\text { nano-chitosan coating nano-iron oxide with } \\
\text { surface modified with crotonaldehyde }\end{array}$ \\
\hline & nano-CIS & 213.58 & pH 6 & 9 & $\begin{array}{l}\text { nano-chitosan coating nano-iron oxide with } \\
\text { surface modified with succinic anhydride }\end{array}$ \\
\hline & EGDE-CS-NZVI beads & 82.6 & - & 48 & $\begin{array}{l}\text { enhanced chitosan beads-supported FeO- } \\
\text { nanoparticles }\end{array}$ \\
\hline & C. sempervirens chitosan & 65.98 & $\mathrm{pH} 5.35$ & 49 & $\begin{array}{l}\text { biodegradable pollen-chitosan } \\
\text { microcapsules }\end{array}$ \\
\hline & $\mathrm{CTS} / \mathrm{SA} / \mathrm{Ca}^{2+} \mathrm{PCDNH}$ & 81.25 & - & 50 & $\begin{array}{c}\text { chitosan/sodium alginate/calcium ion } \\
\text { double-network hydrogel }\end{array}$ \\
\hline & $\begin{array}{c}\mathrm{Fe}_{2} \mathrm{O}_{3} \text { NPs-starch } \\
\text { nanocomposite }\end{array}$ & 70.94 & $\mathrm{pH} 7$ & 7 & $\begin{array}{l}\text { nanoparticulates }\left(\mathrm{Fe}_{2} \mathrm{O}_{3} \mathrm{NPs}\right) \text { with surface } \\
\text { functionality with some hydroxyl groups }\end{array}$ \\
\hline & $\mathrm{SiO}_{2} / \mathrm{Al}_{2} \mathrm{O}_{3} / \mathrm{ZrO}_{2}$ & 9.89 & pH 6 & this work & $\begin{array}{l}\text { ternary oxide silica-alumina-zirconia } \\
\qquad\left(\mathrm{SiO}_{2} / \mathrm{Al}_{2} \mathrm{O}_{3} / \mathrm{ZrO}_{2}\right)\end{array}$ \\
\hline \multirow{11}{*}{$\mathrm{Cu}^{\mathrm{II}}$} & [NPSi-SH] & 58.78 & $\begin{array}{c}0.1 \mathrm{~mol} \mathrm{~L}^{-1} \text { sodium } \\
\text { acetate }\end{array}$ & 5 & $\begin{array}{l}\text { nanoporous silica (NP) synthesized and } \\
\text { modified with thiol moiety [NPSi-SH] }\end{array}$ \\
\hline & nano-CI & 142.98 & pH 7 & 9 & nano-chitosan coating nano-iron oxide \\
\hline & nano-CIC & 270.01 & pH 6 & 9 & $\begin{array}{l}\text { nano-chitosan coating nano-iron oxide with } \\
\text { surface modified with crotonaldehyde }\end{array}$ \\
\hline & nano-CIS & 298.67 & $\mathrm{pH} 6$ & 9 & $\begin{array}{l}\text { nano-chitosan coating nano-iron oxide with } \\
\text { surface modified with succinic anhydride }\end{array}$ \\
\hline & MTPCS & 60.38 & - & 38 & $\begin{array}{l}\text { magnetic chitosan-tripolyphosphate } \\
\text { modified silica-coated adsorbent }\end{array}$ \\
\hline & EGDE-CS-NZVI beads & 67.20 & - & 48 & $\begin{array}{l}\text { enhanced chitosan beads-supported } \\
\text { FeO-nanoparticles }\end{array}$ \\
\hline & C. sempervirens chitosan & 67.10 & pH 5.18 & 49 & $\begin{array}{l}\text { biodegradable pollen-chitosan } \\
\text { microcapsules }\end{array}$ \\
\hline & $\begin{array}{l}\text { N-AHP/chitosan } \\
\text { composite }\end{array}$ & 112.86 & $\mathrm{pH} 7.5$ & 51 & hydroxyapatite/chitosan composite \\
\hline & $\mathrm{CTS} / \mathrm{SA} / \mathrm{Ca}^{2+} \mathrm{PCDNH}$ & 70.83 & - & 50 & $\begin{array}{c}\text { chitosan/sodium alginate/calcium ion } \\
\text { double-network hydrogel }\end{array}$ \\
\hline & $\begin{array}{l}\text { cross-linked Chi-CG } \\
\text { magnetic beads }\end{array}$ & 156.49 & pH 5 & 52 & $\begin{array}{l}\text { magnetic chitosan modified with cysteine- } \\
\text { glutaraldehyde }\end{array}$ \\
\hline & $\mathrm{SiO}_{2} / \mathrm{Al}_{2} \mathrm{O}_{3} / \mathrm{ZrO}_{2}$ & 14.88 & pH 5.35 & this work & $\begin{array}{l}\text { ternary oxide silica-alumina-zirconia } \\
\qquad\left(\mathrm{SiO}_{2} / \mathrm{Al}_{2} \mathrm{O}_{3} / \mathrm{ZrO}_{2}\right)\end{array}$ \\
\hline
\end{tabular}

\section{Conclusions}

The adsorption capacity of $\mathrm{SiO}_{2} / \mathrm{Al}_{2} \mathrm{O}_{3} / \mathrm{ZrO}_{2}$ decreased in the order $\mathrm{Cu}^{\mathrm{II}}>\mathrm{Cd}^{\mathrm{II}}>>\mathrm{Ca}^{\mathrm{II}}$. The model that best describes the adsorption isotherms was the dual-site Langmuir-Freundlich. However, since the adsorption is very low in the sites with high energy, the single-site Langmuir-Freundlich provided a good fit as well. The site responsible for the most ion adsorption was assigned to the $\mathrm{Zr}-\mathrm{OH}$ group. In tests with a sample of produced water, the $\mathrm{SiO}_{2} / \mathrm{Al}_{2} \mathrm{O}_{3} / \mathrm{ZrO}_{2}$ material proved to be quite promising as an adsorbent for alkali and alkali-earth metal ions in high concentrations. The ability to retain anions leads to the presence of both acidic and basic exchange sites. It must be emphasized that the assays with the produced water were carried out in a single condition. The synthesized adsorbent 
Table 4. $\mathrm{X}$-ray fluorescence (XRF) data and mass balances of the assays with produced water for the $\mathrm{SiO}_{2} / \mathrm{Al}_{2} \mathrm{O}_{3} / \mathrm{ZrO}_{2}$ adsorbent

\begin{tabular}{|c|c|c|c|c|c|c|}
\hline & \multicolumn{2}{|c|}{ SiAlZr } & \multicolumn{2}{|c|}{$\mathrm{pH} 5$} & \multicolumn{2}{|c|}{ pH 6} \\
\hline & $\mathrm{XRF} / \%$ & Mass / g & XRF / \% & Mass / g & XRF / \% & Mass / g \\
\hline $\mathrm{SiO}_{2}$ & 59.80 & $1.4 \times 10^{-1}$ & 56.60 & $1.3 \times 10^{-1}$ & 52.45 & $1.3 \times 10^{-1}$ \\
\hline $\mathrm{Al}_{2} \mathrm{O}_{3}$ & 5.70 & $1.3 \times 10^{-2}$ & 3.85 & $8.5 \times 10^{-3}$ & 3.55 & $8.8 \times 10^{-3}$ \\
\hline $\mathrm{ZrO}_{2}$ & 29.70 & $6.9 \times 10^{-2}$ & 23.30 & $5.2 \times 10^{-2}$ & 19.85 & $4.9 \times 10^{-2}$ \\
\hline $\mathrm{HfO}_{2}$ & 0.56 & $1.3 \times 10^{-3}$ & 0.48 & $1.1 \times 10^{-3}$ & 0.38 & $9.0 \times 10^{-4}$ \\
\hline $\mathrm{Cl}$ & 3.90 & $9.1 \times 10^{-3}$ & 5.70 & $1.3 \times 10^{-2}$ & 9.35 & $2.3 \times 10^{-2}$ \\
\hline $\mathrm{SO}_{3}$ & 0.22 & $5.0 \times 10^{-4}$ & 0.24 & $5.0 \times 10^{-4}$ & 0.19 & $5.0 \times 10^{-4}$ \\
\hline $\mathrm{CaO}$ & - & - & 0.73 & $1.7 \times 10^{-3}$ & 0.83 & $2.0 \times 10^{-3}$ \\
\hline $\mathrm{Fe}_{2} \mathrm{O}_{3}$ & - & - & - & - & 0.11 & $3.0 \times 10^{-4}$ \\
\hline $\mathrm{K}_{2} \mathrm{O}$ & - & - & 0.15 & $3.0 \times 10^{-4}$ & 0.18 & $4.0 \times 10^{-4}$ \\
\hline $\mathrm{MgO}$ & - & - & 0.38 & $9.0 \times 10^{-4}$ & 0.48 & $1.2 \times 10^{-3}$ \\
\hline $\mathrm{Na}_{2} \mathrm{O}$ & - & - & 8.30 & $1.9 \times 10^{-2}$ & 12.40 & $3.1 \times 10^{-2}$ \\
\hline$\underline{\mathrm{P}_{2} \mathrm{O}_{5}}$ & - & - & 0.20 & $4.0 \times 10^{-4}$ & 0.19 & $5.0 \times 10^{-4}$ \\
\hline Total & 99.88 & $2.3 \times 10^{-1}$ & 99.93 & $2.2 \times 10^{-1}$ & 99.95 & $2.5 \times 10^{-1}$ \\
\hline
\end{tabular}

has potential to be used for removal of inorganic ions from the produced water at weakly acidic $\mathrm{pH}$. The optimization of the process can broaden the prospects of this new adsorbent for removing metal ions from complex effluents.

\section{Supplementary Information}

Supplementary information is available free of charge at http://jbcs.sbq.org.br as PDF file.

\section{Acknowledgments}

The authors thank to Fundação de Amparo à Pesquisa do Estado do Rio de Janeiro (FAPERJ), Coordenação de Aperfeiçoamento de Pessoal de Nível Superior (CAPES), Conselho Nacional de Desenvolvimento Científico e Tecnológico (CNPq) and Agência Nacional do Petróleo, Gás Natural e Biocombustíveis (ANP) for financial support. The authors thank to Laboratory of Chemical Analysis and Chemical Processing of Ceramics, of the Metallurgical and Materials Engineering Program (PEMM-COPPE-UFRJ) for AAS analysis and CETEM (Mineral Technology Center) for WDXRF analysis.

\section{References}

1. Copello, G. J.; Diaz, L. E.; Campo Dall'Orto, V.; J. Hazard. Mater. 2012, 217-218, 374.

2. Figueiredo, H.; Quintelas, C.; J. Hazard. Mater. 2014, 274, 287.

3. Wang, S.; Peng, Y.; Chem. Eng. J. 2010, 156, 11.

4. Mahmoud, M. E.; Osman, M. M.; Abdel-Aal, H.; Nabil, G. M.; J. Alloys Compd. 2020, 823, 153855.
5. Abdel-Fattah, T. M.; Haggag, S. M. S.; Mahmoud, M. E.; Chem. Eng. J. 2011, 175, 117.

6. Mahmoud, M. E.; J. Liq. Chromatogr. Relat. Technol. 2002, 25, 1187.

7. Mahmoud, M. E.; Nabil, G. M.; Zaki, M. M.; Saleh, M. M.; Int. J. Biol. Macromol. 2019, 137, 455.

8. Mahmoud, M. E.; Masoud, M. S.; Maximous, N. N.; Microchim. Acta 2004, 147, 111.

9. Hosain, A. N. A.; El Nemr, A.; El Sikaily, A.; Mahmoud, M. E.; Amira, M. F.; J. Environ. Chem. Eng. 2020, 8, 104316.

10. Yang, Z.; Peng, H.; Wang, W.; Liu, T.; J. Appl. Polym. Sci. 2010, 116, 2658.

11. Chu, L.; Liu, C.; Zhou, G.; Xu, R.; Tang, Y.; Zeng, Z.; Luo, S.; J. Hazard. Mater. 2015, 300, 153.

12. Ge, H.; Wang, J.; Chemosphere 2017, 169, 443.

13. Lai, C.; Guo, X.; Xiong, Z.; Liu, C.; Zhu, H.; Wu, M.; Zhang, D.; J. Colloid Interface Sci. 2016, 463, 154.

14. Grudtner, V. S.; Weingrill, P.; Fernandes, A. L.; Rev. Bras. Reumatol. 1997, 37, 143.

15. Chen, J. H.; Ni, J. C.; Liu, Q. L.; Li, S. X.; Desalination 2012 , 285, 54.

16. Gao, S.; Yang, J.; Li, Z.; Jia, X.; Chen, Y.; J. Hazard. Mater. 2012, 211-212, 55.

17. Lima, F. H. B.; Calegaro, M. L.; Ticianelli, E. A.; Electrochim. Acta 2007, 52, 3732.

18. Sargentelli, V.; Mauro, A. E.; Massabni, A. C.; Quim. Nova 1996, 19, 290.

19. Produced Water; Ray, J. P.; Engelhardt, F. R., eds.; Springer US: Boston, MA, USA, 1992.

20. Fakhru'l-Razi, A.; Pendashteh, A.; Abdullah, L. C.; Biak, D. R. A.; Madaeni, S. S.; Abidin, Z. Z.; J. Hazard. Mater. 2009, 170, 530 . 
21. Neff, J.; Lee, K.; Deblois, E. In Produced Water: Environmental Risks and Advances in Mitigation Technologies; Lee, K.; Neff, J., eds.; Springer New York: New York, NY, USA, 2011, p. 3-54.

22. Swan, J. M.; Neff, J. M.; Young, P. C.; Environmental Implications of Offshore Oil and Gas Development in Australia: The Findings of an Independent Scientific Review; Australian Petroleum Exploration Association: Sydney, 1994.

23. Ebrahimi, P.; Vilcáez, J.; Sci. Total Environ. 2018, 634, 1054.

24. Sava, B. A.; Diaconu, A.; Elisa, M.; Grigorescu, C. E. A.; Vasiliu, I. C.; Manea, A.; Superlattices Microstruct. 2007, 42, 314.

25. Bouchmella, K.; Mutin, P. H.; Stoyanova, M.; Poleunis, C.; Eloy, P.; Rodemerck, U.; Gaigneaux, E. M.; Debecker, D. P.; J. Catal. 2013, 301, 233.

26. Diniz, K. M.; Gorla, F. A.; Ribeiro, E. S.; do Nascimento, M. B. O.; Corrêa, R. J.; Tarley, C. R. T.; Segatelli, M. G.; Chem. Eng. J. 2014, 239, 233.

27. Ribeiro, M. S.; de Vasconcellos Jr., F. J.; da Fonseca, B. T.; de Souza, F. C.; Soares, F. D. R.; Lima, É. C.; Cabral, M. F.; Ribeiro, E. S.; D’Elia, E.; Anal. Methods 2014, 6, 521.

28. da Fonseca, B. T.; D’Elia, E.; Júnior, J. M. S.; de Oliveira, S. M.; Castro, K. L. S.; Ribeiro, E. S.; J. Mater. Sci. Mater. Electron. 2018, 29, 2159.

29. Silva, C.; Siqueira Jr., J.; Veiga, A.; Muchave, G.; Aranda, D.; Afonso, J.; Ribeiro, E.; Quim. Nova 2019, 42, 513.

30. Pinheiro, E. F.; Rodrigues, J. G. A.; Honório, G. G.; da Cunha, J. N.; de Paula, C. E. R.; de Andrade, D. F.; Ribeiro, E. S.; D'Elia, E.; J. Braz. Chem. Soc. 2019, 30, 1534.

31. de Oliveira, L. L. G.; Ferreira, G. O.; Suquila, F. A. C.; de Almeida, F. G.; Bertoldo, L. A.; Segatelli, M. G.; Ribeiro, E. S.; Tarley, C. R. T.; Food Chem. 2019, 294, 405.

32. Tarley, C. R. T.; Scheel, G. L.; Ribeiro, E. S.; Zappielo, C. D.; Suquila, F. A. C.; J. Braz. Chem. Soc. 2018, 29, 1225.

33. Jung, K. Y.; Park, S. B.; Ihm, S. K.; Appl. Catal., B 2004, 51, 239.

34. Ardizzone, S.; Bianchi, C. L.; Cappelletti, G.; Ionita, M.; Minguzzi, A.; Rondinini, S.; Vertova, A.; J. Electroanal. Chem. 2006, 589, 160.
35. Pal, U.; Sandoval, A.; Madrid, S. I. U.; Corro, G.; Sharma, V.; Mohanty, P.; Chemosphere 2016, 163, 142.

36. Assunpção, R. M. V.; Morita, T.; Manual de Soluções, Reagentes e Solventes, $2^{\text {nd }}$ ed.; Edgard Blucher: São Paulo, SP, Brazil, 2007.

37. de Lima, R. M. G.; Wildhagen, G. R. D. S.; da Cunha, J. W. S. D.; Afonso, J. C.; Quim. Nova 2008, 31, 1237.

38. Jin, X.; Li, K.; Ning, P.; Bao, S.; Tang, L.; Water, Air, Soil Pollut. 2017, 228, 302

39. Wan Ngah, W. S.; Endud, C. S.; Mayanar, R.; React. Funct. Polym. 2002, 50, 181.

40. Naiya, T. K.; Bhattacharya, A. K.; Das, S. K.; J. Colloid Interface Sci. 2009, 333, 14.

41. Prete, M. C.; Tarley, C. R. T.; Chem. Eng. J. 2019, 367, 102.

42. Casarin, J.; Gonçalves Jr., A. C.; Segatelli, M. G.; Tarley, C. R. T.; Chem. Eng. J. 2018, 343, 583.

43. Shafiee, M.; Abedi, M. A.; Abbasizadeh, S.; Sheshdeh, R. K.; Mousavi, S. E.; Shohani, S.; Sep. Sci. Technol. 2020, 55, 1994.

44. Yasemin, B.; Zeki, T.; J. Environ. Sci. 2007, 19, 160.

45. Ribeiro, E. S.; Gushikem, Y.; Electrochim. Acta 1999, 44, 3589.

46. Scholz, F.; Kahlert, H.; Chemical Equilibria in Analytical Chemistry; Springer International Publishing: Cham, 2019.

47. Meroufel, B.; Benali, O.; Benyahia, M.; Benmoussa, Y.; Zenasni, M. A.; J. Mater. Environ. Sci. 2013, 4, 482.

48. Liu, T.; Yang, X.; Wang, Z. L.; Yan, X.; Water Res. 2013, 47, 6691.

49. Sargın, İ.; Kaya, M.; Arslan, G.; Baran, T.; Ceter, T.; Bioresour. Technol. 2015, 177, 1.

50. Tang, S.; Yang, J.; Lin, L.; Peng, K.; Chen, Y.; Jin, S.; Yao, W.; Chem. Eng. J. 2020, 393, 124728.

51. Bazargan-Lari, R.; Zafarani, H. R.; Bahrololoom, M. E.; Nemati, A.; J. Taiwan Inst. Chem. Eng. 2014, 45, 1642.

52. Abou El-Reash, Y. G.; J. Environ. Chem. Eng. 2016, 4, 3835.

53. Vogel, A.; Química Analítica Qualitativa, $5^{\text {th }}$ ed.; Editora Mestre Jou: São Paulo, SP, 1981.

Submitted: October 23, 2020 Published online: March 5, 2021 